\title{
Effect of Laser Acupuncture on the Power of Lower Limb Muscles in Children with Spastic Cerebral Palsy
}

\author{
SAHAR M.A. HASSANEIN, Ph.D., M.D.*; EITEDAL M. DAOUD, Ph.D.**; \\ DALIA M.E. EL MIKKAWY, M.D.*** and NASHWA K.A. EBADA, M.Sc.**
}

The Department of Pediatrics, Faculty of Medicine, Ain Shams University*, Department of Complementary Medicine, Medical Research Division, National Research Centre** and Department of Physical Medicine, Rheumatology \& Rehabilitation, Faculty of Medicine, Ain Shams University***

\begin{abstract}
Background: Cerebral palsy (CP) is defined asneurodevelopmental disorder that occurs due to disturbance in the development of the central nervous system. Laser acupuncture is a technique with minimal side effects and safe for childrenand can be used as an alternative line of treatment in several chronic pediatric diseases.
\end{abstract}

Aim of Study: To assess the efficacy of using a six weeks course of laser acupuncture on muscle strength in children with diplegic or quadriplegic cerebral palsy.

Patients and Methods: A randomized controlled trial; that was conducted in the neuropediatric clinic of the National Research Centre, Egypt and Outpatient Clinic of Ain Shams Children Hospital from 2018 to February 2020. It included 40 children with spastic $\mathrm{CP}$. They were randomly assigned to two equal groups $(n=20)$, laser acupuncture group and control group. Both groups received physiotherapy for successive 6 weeks; while only the study group also received low-level laser $650 \mathrm{~nm}$ with $50 \mathrm{~mW}$ powers that was applied at each acupoint for 30 s giving an energy density of $1.8 \mathrm{~J} / \mathrm{cm}^{2}$ ).

Results: Power of hip flexors and knee extensors were significantly increased in laser acupuncture group compared to the control group, $p<0.001$.

Conclusion: Laser acupuncture has a beneficial effect on hip flexors and knee extensors muscles strength compared with the control group in children with spastic cerebral palsy.

Key Words: Laser-Acupuncture - Cerebral palsy-Muscle power - Lower limb.

\section{Introduction}

CEREBRAL palsy (CP) is defined asneurodevelopmental disorder that occurs due to disturbance in the development of the central nervous system during prenatal, perinatal, and postnatal period [1]

Cerebral palsy is commonly associated by sensation, communication, perception, cognition and/or

Correspondence to: Dr. Nashwa K.A. Ebada

E-Mail : nashwaebada84@hotmail.com behavioral disorders, and/or by a seizure disorder". It affects over 17 million people worldwide and is the most common physical disability in childhood [2].

In Egypt it has an estimated prevalence of 2.04 per 1000 live births. Prognosis of cerebral palsy patients usually relies on the type and severity of the pathological neurological insult and if there are associated medical comorbidities [3].

Spastic cerebral palsy is by far the most common type of overall cerebral palsy, occurring in about $70 \%$ of all cases [4].

Spasticity is a result of upper motor neuron lesion in the brain as well as the corticospinal tract or the motor cortex. It is also considered to be a critical factor that prevents movements in these patients. In addition to motor impairment, children with cerebral palsy may also experience learning and feeding difficulties, and have seizure conditions. Moreover, many children may experience sensory impairments and have difficulties communicating [3]

Different conventional therapies to increase the function and minimize complications of cerebral palsy have been concentrated [4]

Acupuncture is an integral part of Chinese medicine, and considered as an effective nonpharmacological treatment in many pediatric problems. It also has been growing in prominence in many parts of the world [5].

According to Chinese medicine, it is believed that acupuncture can regulate the flow of energy force called Qi through the meridians and channels of the body in order to correct the imbalance of energy and restore natural internal homeostasis [6] 
Laser acupuncture is a technique with minimal side effects and safe for children. Low intensity laser is applied on acupuncture points which induce photobiostimulation reaction on tissues and cells [7].

It has been found that photobiostimulation accelerates tissue repair, regeneration, increase angiogenesis, reduces pain and inflammation as well as stimulate the formation of new muscle fibers [7].

Laser acupuncture does not include mechanical effect like that of manual acupuncture; on the other hand, it has the same mechanism in stimulation of the signal transduction pathway [8].

Aim of the work: This study was conducted to investigate the effect of laser acupuncture on muscle power.

\section{Patients and Methods}

This is a randomized clinical trial included forty patients of both sexes ( 31 boys and 9 girls) aged between 2 and 5 years old diagnosed as spastic $\mathrm{CP}$ attended the neuropediatric clinic of the National Research Centre, Egypt and Outpatient Clinic of Ain Shams Children hospital from 2018 to February 2020.

\section{Inclusion criteria:}

1-Any child aged from 2 to 5 years having diplegic or quadriplegic cerebral palsy and complaining of spasticity.

2- Children should be free from convulsions for one year.

\section{Exclusion criteria:}

1- History of convulsions within the year of enrolment.

2- Presence of muscle contracture.

3- Mental retardation.

All patients were randomly assigned into two equal groups, the laser group composed of 20 patients and the control group composed of 20 patients.

All patients were subjected to regular sessions of physical therapy (according to each patient condition) in the same frequency ( 3 sessions per week, 1 hour each).

The laser group received laser acupuncture at a frequency of 2 sessions per week for successive six weeks in addition to physiotherapy.
Assessments of power of muscles of lower limbs (hip flexors and knee extensors) were performed before and after completing all treatment sessions by using the medical research council grading of muscle power. It consists of six grades (scale of 0-5) in relation to the maximum range expected for that muscle Table (1) [9]

Table (1): Medical research council grading of muscle power.

\begin{tabular}{cl}
\hline Grade & Description \\
\hline 0 & Complete paralysis \\
1 & Flicker of contraction present \\
2 & Movement possible if gravity eliminated \\
3 & Movement against gravity but not against \\
& resistance \\
4 & Movement possible against resistance but \\
5 & less than normal power \\
\hline
\end{tabular}

The instrument used was Diode laser device. It was used for biostimulation of the acupuncture points. It has a pen probe with a diameter of $1 \mathrm{~cm}$. The device has a wavelength of $808 \mathrm{~nm}$ in the red region of the visible spectrum and a power output of $0-250 \mathrm{~mW}$. The probe was applied with slight pressure for 30 second at each point. The laser group received laser acupuncture at ST36, ST35, ST40, SP6 and LR3 points. The control group received placebo laser acupuncture without activated laser light at the same points.

Laser parameters used in this study are listed in Table (2).

Table (2): Laser parameters.

Power output $50 \mathrm{~mW}$
Wave length $808 \mathrm{~nm}$
Beam spot diameter $1 \mathrm{~cm}$
Beam spot area $0.785 \mathrm{~cm}^{2}$
Power density $60 \mathrm{~mW} / \mathrm{cm}^{2}$
Energy density/point $1 . \mathrm{J} / \mathrm{cm}^{2}$
Treatment time/point $30 \mathrm{~s}$
Number of points 5 points

Statistical analysis:

Statistical analysis was carried out using the SPSS computer package version 21.0 (SPSS Inc., Chicago, IL, USA). Fischer's Exact Test (FET) was used to assess the differences in frequency of qualitative variables while Mann-Whitney U-test was applied to assess the differences in means of quantitative variables. The statistical methods were verified, assuming a significant level of $p<0.05$ and a highly significant level of $p<0.001$. 


\section{Results}

Table (3): Age and sex distribution in both groups.

\begin{tabular}{llll}
\hline Variables & $\begin{array}{c}\text { Laser } \\
(\mathrm{N}=20)\end{array}$ & $\begin{array}{l}\text { Control } \\
(\mathrm{N}=20)\end{array}$ & $p$-value \\
\hline Age (years): & & & \\
$\quad$ Mean \pm SD & $3.1 \pm 1.1$ & $3.2 \pm 1.0$ & $\wedge 0.662$ \\
$\quad \begin{array}{l}\text { Range } \\
\text { Sex }(n, \%):\end{array}$ & $2.0-5.0$ & $2.0-5.0$ & \\
$\quad$ Male & $14(70.0 \%)$ & $17(85.0 \%)$ & $\S 0.451$ \\
$\quad$ Female & $6(30.0 \%)$ & $3(15.0 \%)$ & \\
\hline
\end{tabular}

${ }^{\wedge}$ Independent $t$-test. \#Chi square test. $\S$ Fisher's Exact test.

There is no significant difference between both groups in age and sex distribution.

Table (4): Basesline growth and milestones of both groups.

\begin{tabular}{llll}
\hline Variables & $\begin{array}{c}\text { Laser } \\
(\mathrm{N}=20)\end{array}$ & $\begin{array}{c}\text { Control } \\
(\mathrm{N}=20)\end{array}$ & $p$-value \\
\hline Mile stones: & & & \\
$\quad$ Head support & $13(65.0 \%)$ & $16(80.0 \%)$ & $\# 0.288$ \\
$\quad$ Sitting & $14(70.0 \%)$ & $17(85.0 \%)$ & $\S 0.451$ \\
$\quad$ Standing & $8(40.0 \%)$ & $10(50.0 \%)$ & $\# 0.525$ \\
Walking & $6(30.0 \%)$ & $8(40.0 \%)$ & $\# 0.507$ \\
$\quad$ Climb stairs & $1(5.0 \%)$ & $2(10.0 \%)$ & $\S 0.999$ \\
Muscle atrophy & $1(5.0 \%)$ & $2(10.0 \%)$ & $\S 0.999$ \\
\hline${ }^{\prime}$ Independent $t$-test. & \#Chi square test. & \multicolumn{3}{l}{ §Fisher's Exact test. }
\end{tabular}

No significant differences between both groups in baseline growth mile stones.

Table (5): Comparison regarding power of hip flexors.

\begin{tabular}{|c|c|c|c|}
\hline Time & $\begin{array}{l}\text { Laser } \\
(\mathrm{N}=20)\end{array}$ & $\begin{array}{l}\text { Control } \\
(\mathrm{N}=20)\end{array}$ & $\begin{array}{c}\wedge p- \\
\text { value }\end{array}$ \\
\hline $\begin{array}{l}\text { Right } \\
\text { Baseline: (1 1st-3rd IQ) } \\
\text { Median } \\
\text { Range }\end{array}$ & $\begin{array}{l}3.0(3.0-3.0) \\
2.0-4.0\end{array}$ & $\begin{array}{l}3.0(3.0-3.8) \\
2.0-4.0\end{array}$ & 0.642 \\
\hline $\begin{array}{l}\text { After: } \\
\text { Median (1st-3rd } \\
\text { Range }\end{array}$ & $\begin{array}{l}4.0(3.0-4.0) \\
3.0-5.0\end{array}$ & $\begin{array}{l}3.0(3.0-3.8) \\
2.0-4.0\end{array}$ & $0.002^{*}$ \\
\hline $\begin{array}{l}\text { Change: (1st-3rd } \\
\text { Median } \\
\text { Range }\end{array}$ & $\begin{array}{l}1.0(0.0-1.0) \\
0.0-2.0\end{array}$ & $\begin{array}{l}0.0(0.0-0.0) \\
0.0-0.0\end{array}$ & $<0.001 *$ \\
\hline$\# p$-value & $0.001 *$ & 0.999 & \\
\hline $\begin{array}{l}\text { Left } \\
\text { Baseline: (1st-3rd } \mathrm{IQ}) \\
\text { Median } \\
\text { Range }\end{array}$ & $\begin{array}{l}3.0(3.0-4.0) \\
2.0-4.0\end{array}$ & $\begin{array}{l}3.0(3.0-3.8) \\
2.0-4.0\end{array}$ & 0.812 \\
\hline $\begin{array}{l}\text { After: } \\
\text { Median (1st-3rd } \\
\text { Range }\end{array}$ & $\begin{array}{l}4.0(4.0-4.0) \\
3.0-4.0\end{array}$ & $\begin{array}{l}3.0(3.0-3.8) \\
2.0-4.0\end{array}$ & $<0.001 *$ \\
\hline $\begin{array}{l}\text { Change: (1st-3rd } \\
\text { Median } \\
\text { Range }\end{array}$ & $\begin{array}{l}1.0(0.0-1.0) \\
0.0-2.0\end{array}$ & $\begin{array}{l}0.0(0.0-0.0) \\
0.0-0.0\end{array}$ & $<0.001 *$ \\
\hline$\# p$-value & $0.001 *$ & 0.999 & \\
\hline
\end{tabular}

Change=After-baseline (negative values indicate reduction)

^Mann Whitney test. \#Wilcoxon signed rank test. *Significant.
Regarding power of hip flexors, there was no significant difference in baseline power. After intervention power of hip flexors was significantly increased in laser group only.

Table (6): Comparison regarding power of knee extensors.

\begin{tabular}{|c|c|c|c|}
\hline Time & $\begin{array}{l}\text { Laser } \\
(\mathrm{N}=20)\end{array}$ & $\begin{array}{l}\text { Control } \\
(\mathrm{N}=20)\end{array}$ & $\begin{array}{c}\wedge p- \\
\text { value }\end{array}$ \\
\hline $\begin{array}{l}\text { Right } \\
\text { Baseline: } \\
\text { Median (1 st-3rd IQ) } \\
\text { Range }\end{array}$ & $\begin{array}{l}3.0(2.3-3.0) \\
2.0-4.0\end{array}$ & $\begin{array}{l}3.0(3.0-3.8) \\
2.0-4.0\end{array}$ & 0.331 \\
\hline $\begin{array}{l}\text { After: } \\
\text { Median (1 st-3rd IQ) } \\
\text { Range }\end{array}$ & $\begin{array}{l}4.0(4.0-4.0) \\
2.0-4.0\end{array}$ & $\begin{array}{l}3.0(3.0-3.8) \\
2.0-4.0\end{array}$ & $0.001 *$ \\
\hline $\begin{array}{l}\text { Change: } \\
\text { Median (1 st-3rd IQ) } \\
\text { Range }\end{array}$ & $\begin{array}{l}1.0(0.3-1.0) \\
0.0-2.0\end{array}$ & $\begin{array}{l}0.0(0.0-0.0) \\
0.0-0.0\end{array}$ & $<0.001 *$ \\
\hline$\# p$-value & $<0.001 *$ & 0.999 & \\
\hline $\begin{array}{l}\text { Left } \\
\text { Baseline: (1st-3rd IQ) } \\
\text { Median } \\
\text { Range }\end{array}$ & $\begin{array}{l}3.0(2.3-3.8) \\
2.0-4.0\end{array}$ & $\begin{array}{l}3.0(3.0-3.8) \\
2.0-4.0\end{array}$ & 0.824 \\
\hline $\begin{array}{l}\text { After: } \\
\text { Median (1st-3rd } \\
\text { Range }\end{array}$ & $\begin{array}{l}4.0(4.0-4.0) \\
3.0-4.0\end{array}$ & $\begin{array}{l}3.0(3.0-3.8) \\
2.0-4.0\end{array}$ & $<0.001 *$ \\
\hline $\begin{array}{l}\text { Change: } \\
\text { Median (1 st-3rd IQ) } \\
\text { Range }\end{array}$ & $\begin{array}{l}1.0(0.0-1.0) \\
0.0-2.0\end{array}$ & $\begin{array}{l}0.0(0.0-0.0) \\
0.0-0.0\end{array}$ & $<0.001^{*}$ \\
\hline$\# p$-value & $0.001 *$ & 0.999 & \\
\hline
\end{tabular}

Change=After-baseline (negative values indicate reduction).

${ }^{\wedge}$ Mann Whitney test. \#Wilcoxon signed rank test. *Significant.

Regarding power of knee extensors, there was no significant difference in baseline power. After intervention power of knee extensors was significantly increased in laser group only.

\section{Discussion}

Laser acupuncture is an analgesic technique that commonly used for analgesia in pediatric patients and can be easily performed, it also has noninvasive characteristic, and almost does not have side effects if it is performed correctly.

This study is one of the few studies that evaluate the efficacy and safety of using laser acupuncture for improving muscle power in children with spastic cerebral palsy.

Forty spastic children participated in this study. They were assigned randomly into two groups of equal number, 20 patients each. The ages (mean \pm standard deviation) of laser group and control group were (3.1 \pm 1.1$)$ and $(3.2 \pm 1.0)$ respectively. Comparing means values of the two groups revealed non-significant differences ( $p$-value 0.662 ). The distribution of males and females in laser group 
were $70 \%$ and $30 \%$. While in control group they were $85 \%$ and $15 \%$ respectively. There was no significant difference between the studied groups regarding demographic characteristics and growth milestones.

In this study Medical Research council grading (MRC) is used for assessment of the power of hip flexors and knee extensors. Despite the improvement of the scores in both groups, it was statistically significant improved in cases group only $(p<0.001)$. This improvement could be explained by the possible mechanism of action of Laser acupuncture, it is likely to include many clinical effects such as anti-inflammatory, cell healing and neural modulation. It also has an analgesic effect and can improve pain and stiffness of knee leading to improvement of the power and function of lower limb muscles [10]

Moreover, in a study on six years old patient with cerebral palsy who was treated using Chinese scalp acupuncture. The Speech I, Speech II, Motor, Foot motor and sensory, and Balance areas were stimulated once per week, then every other week for 15 sessions. His dysarthria, ataxia, and weakness of legs, arms, and hands showed significant improvement [11].

Furthermore, a randomized controlled trial carried out on young men $(n=43)$ were randomly assigned to four groups: control; manual acupuncture and electroacupuncture on two acupoints (ST36 and ST-39); and electroacupuncture on two nonacupoints (on tibialis anterior muscle). The non-control groups received acupuncture or electroacupuncture (15 to 30 minutes) on the right leg in each session, 3 sessions per week for 6 weeks. Assessment of the maximal strength in isometric ankle dorsiflexion of both legs was done before and after the experimental period. Repeated measures analysis of variance identified significant and similar strength gains (range, 35\%-64\% in the right leg and 32\%-49\% in the left leg; $p=0.01$ ) in all acupuncture groups, but not in the control group [12].

In consistency with; the results observed in this study, a trial by Hübscher et al., 2010. In which a total of 33 recreational athletes $(25.2 \pm 2.8$ years; 13 women) were randomized to receive acupuncture, sham acupuncture (needling at non-acupuncture points) and placebo laser acupuncture (deactivated laser device) in a double-blind fashion with one week between trials. Measurements were performed before and after treatment. The difference in the mean change in maximum isometric volun- tary force (MIVF) of quadriceps muscle from baseline between acupuncture and sham laser acupuncture was statistically significant $(p=005)$ [13]

In another study by Huang et al., 2015, fifty male volunteers with an age range of 19-27 years were randomly assigned into five groups: (1) Manual acupuncture and (2) Electroacupuncture at two acupoints (ST-36 and ST-39); (3) Manual acupuncture and (4) Electroacupuncture at two nonacupoints on the tibialis anterior muscle; and (5) Control group. Assessment of maximal isometric ankle dorsiflexion strength and muscle activation of both legs were assessed pre, post, 2 weeks post, and 3 weeks post the experimental period. Mixed models (linear) with repeated-measures analysis identified significant strength gains $(p<0.01)$ after the intervention period in both limbs, A significant improvement in muscle activation $(p<0.01)$ was also observed in both legs in the intervention groups [14]

Conclusion: Laser acupuncture is a safe, noninvasive, painless treatment method that is particularly suitable for application in children. Based on the results of our study and previous studies, laser acupuncture appears to be effective in improving muscle power in children with cerebral palsy.

Recommendations: Laser acupuncture session to be used for treatment of cerebral palsy children to improve their motor power, together with regular exercises. Further studies are recommended to investigate the effect of laser acupuncture on gait pattern, balance and onset of independent walking in children spastic cerebral palsy.

\section{References}

1- TRABACCA A., VESPINO T., RUSSO L., et al.: Multidisciplinary rehabilitation for patients with cerebral palsy: Improving long-term care. J. Multidiscip Healthc, 9: 45562, 2016.

2- PATEL D.R., NEELAKANTAN M., PANDHER K., et al.: Cerebral palsy in children: a clinical overview. TranslPediatr, 9 (Suppl 1): S125-35, 2020.

3- MATHEWSON M.A. and LIEBER R.L.: Pathophysiology of Muscle Contractures in Cerebral Palsy. Phys. Med. Rehabil Clin. N. Am., 26 (1): 57-67, 2015.

4- DABBOUS O.A., MOSTAFA Y.M., ELNOAMANY H.A. et al.: Laser acupuncture as an adjunctive therapy for spastic cerebral palsy in children. Lasers Med. Sci., 31 (6): 1061-7, 2016.

5- CRAMER H., CHUNG V.C.H., LAUCHE R., et al.: Characteristics of acupuncture users among internal medicine patients in Germany. Complement Ther. Med., 23 (3): 423-9, 2015.

6- WANG C., LEE Y.C., WU M., et al.: Trends in the utilization of acupuncture among children in Taiwan from 
2002 to 2011: A nationwide population-based study. BMC Complement Altern Med., 21; 19 (1): 328, 2019.

7- TSUK S., LEV Y.H., FOX O., et al.: Does Photobiomodulation Therapy Enhance Maximal Muscle Strength and Muscle Recovery? J. Hum. Kinet, 21 (73): 135-44, 2020.

8- PUTRI D.E., SRILESTARI A., ABDURROHIM K., et al.: The Effect of Laser Acupuncture on Spasticity in Children with Spastic Cerebral Palsy. J. Acupunct Meridian Stud., 13 (5): 152-6, 2020.

9- PATERNOSTRO T., GRIM-STIEGER M., POSCH M., et al.: Reliability and validity of the Medical Research Council (MRC) scale and a modified scale for testing muscle strength in patients with radial palsy. J. Rehabil Med., 40 (8): 665-71, 2008.

10- WU S.Y., LIN C.H., CHANG N.J., et al.: Combined effect of laser acupuncture and electroacupuncture in knee osteoarthritis patients: A protocol for a randomized controlled trial. Medicine (Baltimore), 99 (12): e19541, 2020.

11-HAO J.J., ZHONGREN S., XIAN S., et al.: Chinese scalp acupuncture for cerebral palsy in a child diagnosed with stroke in utero. Glob. Adv. Health Med., 1 (1): 14-7, 2012.

12- ZHOU S., HUANG L-P., LIU J., et al.: Bilateral effects of 6 weeks' unilateral acupuncture and electroacupuncture on ankle dorsiflexors muscle strength: A pilot study. Arch Phys. Med. Rehabil, 93 (1): 50-5, 2012.

13-HUBSCHER M., VOGT L., ZIEBART T., et al.: Immediate effects of acupuncture on strength performance: A randomized, controlled crossover trial. Eur. J. Appl Physiol, 110 (2): 353-8, 2010.

14- HUANG L.P., ZHOU S., AO M., et al.: Unilateral intramuscular needling can improve ankle dorsiflexor strength and muscle activation in both legs. J. Exerc Sci. Fit, 13 (2): 86-93, 2015.

\section{تأثير استخدام الليزد على نقاط الإبر الصينية

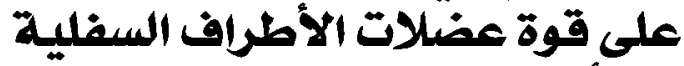 للدى الأطفال الهصابين بالشلال الدافل الدماغى}

الثلل الدماغى هو اضطراب في النمو العصبى يحدث نتيجة اضطراب في تطور الجهاز العصبى المركزى. تتميز تقنية استخدام الليزد في تحفيز نقاط الإبر الصينية بأنها آمنة للأطفال.

وتهدف هذه الدراسة إلى تقييم فعالية استخدام تحفيز نقاط الإبر الصينية لمدة ستة أسابيع باستخدام الليز على قوة العضلات لدى الأطفال

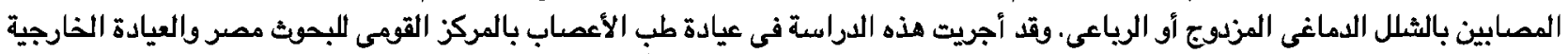

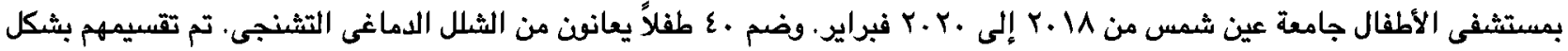

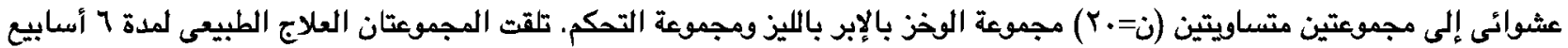

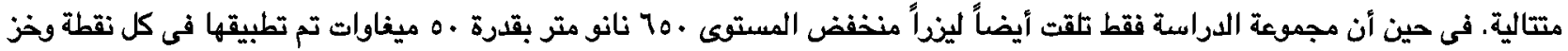

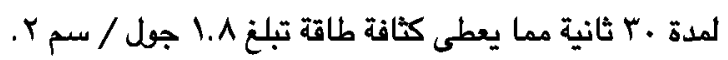

وقد أسفرت نتائج الدراسة الحالية عن حدوث تحسن ملحوظ في قوة عضلات الأطراف السفلية للمرضى في مجموعة الوخز بالإبر الصينية الذين تم معالجتهم بتقنية استخدام الليزي في تحفيز نقاط الإبر الصية الصينية. توصيات البحث: استخدام تقنية الليز في تحفيز نقاط الإبر الصينية فى علاج المرضى المصابين بالشلل الدماغى التيبسى. 